\title{
Os discursos da Rádio Rural de Natal nos anos 1960: um capítulo da relação Comunicação/ Educação no Brasil*
}

Adriano Lopes Gomes

Pós-doutor pela Universidade Nova de Lisboa. Doutor em Educação pela Universidade Federal do Rio Grande do Norte - UFRN, onde é prof. dr. adjunto do Departamento de Comunicação Social e dos programas de pós-graduação: Estudos da Mídia e Estudos da Linguagem.

Coordenador da Base de Pesquisa Comunicaşão, Cultura e Mídia.

E-mail: adrianogomes@cchla.ufrn.br

Edivânia Duarte Rodrigues

Doutoranda em Estudos da Linguagem pela Universidade Federal do Rio Grande do Norte PPgEL - UFRN, pesquisadora da Base de Pesquisa Comunicação, Cultura e Mídia na mesma instituição.

E-mail: edivania_duarte@yahoo.com.br

Resumo: Este artigo analisa o discurso argumentativo desenvolvido pelo Movimento de Educação de Base (MEB) por intermédio das aulas transmitidas pela Emissora de Educação Rural de Natal. Revela as técnicas argumentativas na produção discursiva das aulas, identificando as posições ideológicas defendidas, os formatos no rádio e o caráter dialógico dessa interação. A educação a distância por meio da emissora Rural promoveu um diálogo com os alunos, instigando a persuasão dos jovens e adultos, no que se refere à ação sobre a realidade para transformá-la, segundo os desejos de justiça social da classe popular.

Palavras-chave: MEB, Rádio Rural de Natal, aulas radiofônicas, discurso, argumentação.
Abstract: This article analyzes the argumentative discourse developed by the Basis Educational Movement (MEB) throughout the classes broadcasted by Natal Rural Education Radio. It reveals the argumentative techniques in the discursive production of the classes, identifying the defended ideological positions, the formats in the radio, and the dialogical characteristic of that interaction. The distance education throughout the Rural broadcasting promoted a dialogue with the students, motivating the youths' and the adults' persuasion, regarding to the action to transform the reality, according to the social justice desires of the popular class.

Keywords: MEB, Natal Rural Radio, radio classes, discourse, argumentation.

Este artigo realiza uma análise discursivo-argumentativa das aulas radiofônicas da Emissora de Educação Rural de Natal que integraram o projeto educativo do Movimento de Educação de Base (MEB) surgido em 1961. Coordenado pela

Recebido: 23.10 .2010

Aprovado: 27.05.2011

* O artigo faz parte da dissertação de mestrado intitulada - Estratégias argumentativas na construção do discurso ideológico: um estudo da produção didático-pedagógica do MEB -, UFRN, 2009 - com apoio do Conselho Nacional de Desenvolvimento Científico e Tecnológico - CNPq. 
comunicação \& educação • Ano XVI • número 2 • jul/dez 2011

1. PÊCHEUX, Michel. Semântica e discurso: uma crítica à afirmação do óbvio. Trad. Eni Pulcinel Orlandi. 3. ed. Campinas: Editora da UNICAMP, 1997.

2. PERELMAN, Chaïm; TYTECA, Lucie Olbrechts. Tratado da argumentação: a nova retórica. Trad. Maria Ermantina Galvão. São Paulo: Martins Fontes, 1996.
Conferência Nacional dos Bispos do Brasil (CNBB) e financiado pelo Estado, o MEB, utilizando o rádio, levou educação de base a jovens e adultos de diversas regiões do Brasil, sobretudo nas zonas rurais, pautando a alfabetização na conscientização do aprendiz.

No âmbito do Rio Grande do Norte, a Rádio de Educação Rural era a principal expoente da educação a distância e as aulas veiculadas pela emissora consistiam no ensino de conteúdos instrucionais e transmissão de discursos voltados para convencer e persuadir o aluno na tomada de posição e defesa pela transformação da estrutura socioeconômica desigual do país. Nessa época, o Brasil possuía um grande contingente de analfabetos, e o rádio, na qualidade de um dos principais veículos de comunicação, estava incumbido de atingir os lugares mais remotos.

Assim sendo, analisamos algumas técnicas argumentativas que estruturam as aulas radiofônicas, demarcando posições e promovendo o convencimento e a persuasão dos alunos às teses apresentadas. Atentamos ainda para as condições de produção, efeitos de sentido do discurso e os formatos radiofônicos, entendendo o rádio como mediação tecnológica entre professores e alunos.

Acreditamos que desenvolver esse estudo nos permite colaborar com a memória histórica do MEB e do rádio no processo de educação do povo brasileiro. Possibilita, ainda, um gesto de leitura sobre as aulas radiofônicas e seus formatos, encarando-as como instrumento discursivo de consequências políticas e sociais no campo da inserção do sujeito consciente dos seus deveres e direitos, capaz de atuar na estrutura histórica e social do local em que vive.

\section{BASES TEÓRICAS DO ESTUDO: DISCURSO, ARGUMENTAÇÃO E DIALOGISMO}

Para realizarmos a leitura dos discursos argumentativos transmitidos pela Rádio Rural, numa perspectiva dialógica da linguagem, recorremos à análise do discurso (AD), da Escola Francesa, à teoria da argumentação e ao dialogismo. A primeira corrente teórica nos possibilita encarar o discurso como um objeto de análise, o qual articula a linguagem e a exterioridade, compreendendo o sentido como polissêmico. Dessa forma, a AD vê as condições de produção como constitutivas de sentido, defendendo que esse sentido não pode ser visto como literal, mas sim como possibilidades, efeitos de sentido. Isso porque, segundo Pêcheux ${ }^{1}$, as classes não são indiferentes à língua, de forma que todo processo discursivo se inscreve numa relação ideológica de classes. Portanto, as formações discursivas do discurso, determinadas pelas formações ideológicas correspondentes, comportam palavras que se referem às posições ideológicas de quem as emprega.

Os discursos dos quais tratamos estão estruturados por técnicas argumentativas definidas de acordo com a teoria da argumentação ${ }^{2}$, como quaisquer recursos verbais e não verbais que estejam relacionados ao ouvinte num processo de convencimento e/ou persuasão. Destacamos três técnicas: os recursos 
de presença, que visam ilustrar a tese que se pretende defender; a modalidade interrogativa, que é uma forma de se dirigir aos ouvintes com questionamentos, supondo um acordo implícito sobre o objeto entre o orador e o auditório; e os valores, caracterizados como objetos de acordo que atingem grupos particulares.

As técnicas argumentativas buscam provocar ou aumentar a adesão do auditório às teses que lhes são apresentadas, visto que "argumentar é a arte de convencer e persuadir" como o orador, e persuadi-lo é fazer com que esse alguém realize algo que o orador deseja que se realize.

Entretanto, vale enfatizar que a utilização dessas técnicas não limita o entendimento do discurso aos desejos do orador, como se o sujeito ouvinte não pudesse atribuir outros sentidos ao discurso, pois, quando argumenta, o orador quer convencer o ouvinte, numa interação dialógica, quanto à plausibilidade de seus argumentos e de sua tese - a ideia geral que se quer vender.

Não vemos a argumentação em oposição ao diálogo, pelo contrário, entendemos o ato de argumentar como uma postura que não quer impor um modo de pensar pela força ou violência, mas requer do sujeito/ouvinte uma reflexão junto com o orador, dando-lhe fundamentos para certas posições e suscitando do ouvinte outras leituras possíveis. Nesse sentido, a argumentação define posições, mas deixa para o outro (interlocutor) a função de aprová-las ou de refutá-las, já que o outro é visto numa perspectiva ativa como um sujeito capaz de refletir.

Conforme Bakhtin, toda linguagem é dialógica em menor ou maior grau. Assim, entendemos a interação proposta pelos meios de comunicação como sendo dialógica, já que o receptor deve ser sempre presumido durante a produção. Ao consumir a mensagem, o interlocutor produz sentidos de maneira a compreender o que foi dito. Essa compreensão é entendida por Bakhtin como uma forma de resposta. Na concepção do autor, devemos compreender diálogo num sentido amplo, isto é, "não apenas a comunicação em voz alta, de pessoas colocadas face a face, mas toda comunicação verbal de qualquer tipo que seja"4 .

Portanto, enfatizamos o caráter dialógico da interação pelo rádio, visto que se presume um interlocutor para o diálogo, mesmo que ele esteja espacialmente distante, com vistas a promover uma ação a distância, termo cunhado por Thompson ${ }^{5}$, quando defende que nos meios de comunicação a produção das mensagens é orientada para atender os receptores, mesmo que eles não possam interferir diretamente no curso do conteúdo.

\section{A EDUCAÇÃO POPULAR NA FUNDAMENTAÇÃO DO MEB}

A educação popular vincula-se à concepção democrática de cultura, concebendo-a como um instrumento de promoção humana porque "É popular a cultura quando é comunicável ao povo" ${ }^{6}$. Seguindo esses pressupostos de cultura popular, surgem os Movimentos de Cultura Popular (MCP) na década de 1960, que propunham a libertação do homem como produtor
3. ABREU, Antônio Suárez. A arte de argumentar: gerenciando razão e emoção. 3. ed. São Paulo: Ateliê Editorial, 2001. p. 25.

4. BAKHTIN, Mikhail. Marxismo e filosofia da linguagem. São Paulo: Hucitec, 1995. p. 123.

5. THOMPSON, John B. A mídia e a modernidade: uma teoria social da mídia. Petrópolis (RJ): Vozes, 1998.

6. FÁVERO, Osmar (Org.). Cultura popular e educação popular: memória dos anos 60. 2. ed. Rio de Janeiro: Edições Graal, 2001. p. 23. 
de expressões culturais e não mero receptor da cultura dominante, já que todo homem produz cultura. Esses movimentos questionavam a realidade de desigualdades culturais e socioeconômicas do Brasil e buscavam, a partir da educação popular, soluções para os problemas do povo. Sendo assim, os MCP propunham uma reforma revolucionária na realidade brasileira, empreendendo soluções imediatas que culminariam na execução do seu objetivo principal: a transformação material da sociedade.

O MEB, considerado um MCP, utilizou a alfabetização como um dos seus principais instrumentos de intervenção social. Defendia uma reação à cultura e à educação que privilegiava somente as classes dominantes. Por esse motivo, propunha o desenvolvimento de uma educação popular que, tomada pelas concepções de cultura popular, buscava alfabetizar os alunos, relacionando-os com suas realidades sociais, instigando-os a uma postura crítica. A educação passou a ser vista como uma possibilidade de mudança das estruturas sociais e econômicas injustas do país. Portanto, para que evidenciasse tal função, deveria ser uma educação criticizadora, com métodos ativos, que libertasse os alunos pela conscientização, instrumentalizando-os a tomarem suas próprias atitudes e escolhas.

Nesse sentido, a pedagogia do MEB inspirou-se nas reflexões do educador Paulo Freire, pautando o ensino no método ativo de caráter dialogal. O objetivo era fazer com que os educandos pensassem sobre a realidade social em que estavam inseridos, uma educação que "proporciona ao homem muito mais que o simples alfabetizar, pois, através da discussão de problemas locais, regionais e nacionais, torna-o mais crítico e o leva posteriormente a se conscientizar e a se politizar"7. Foi, portanto, dentro desse contexto que o MEB promoveu uma educação popular para jovens e adultos no Brasil, tendo no Rio Grande do Norte a Emissora de Educação Rural como principal disseminadora.

\section{O MEB E A RÁDIO RURAL NA EDUCAÇÃO DE JOVENS E ADULTOS}

O rádio já nasceu com o perfil educativo, desde a instalação da Rádio Sociedade do Rio de Janeiro, na década de 1920. Entretanto, foi a partir do surgimento da Emissora de Educação Rural de Natal, em 10 de agosto de 1958, que a programação educativa, especialmente o conteúdo instrucional, tomou contornos expressivos no rádio brasileiro por meio das escolas radiofônicas.

A Emissora de Educação Rural de Natal surgiu a partir da idealização de Dom Nivaldo Monte e Dom Eugênio Sales que, inspirados pela Rádio Sutatenza, da Colômbia - primeira rádio educativa do continente americano -, instituíram as escolas radiofônicas para alfabetizar jovens e adultos pelo rádio. Chamada depois de Rádio Rural de Natal, a emissora fazia parte do Serviço de Assistência Rural (SAR), integrando o Movimento de Natal que, por sua vez,

7. CARDOSO, Aurenice. Conscientização e alfabetização. In: FÁVERO, Osmar (Org.). Cultura popular e educação popular: memória dos anos 60 , cit., p. $161-172$ consistia em ações sociorreligiosas desenvolvidas pela Arquidiocese de Natal (RN), no período de 1943 a 1964, destacando-se as escolas radiofônicas como instrumentos de intervenção social. 


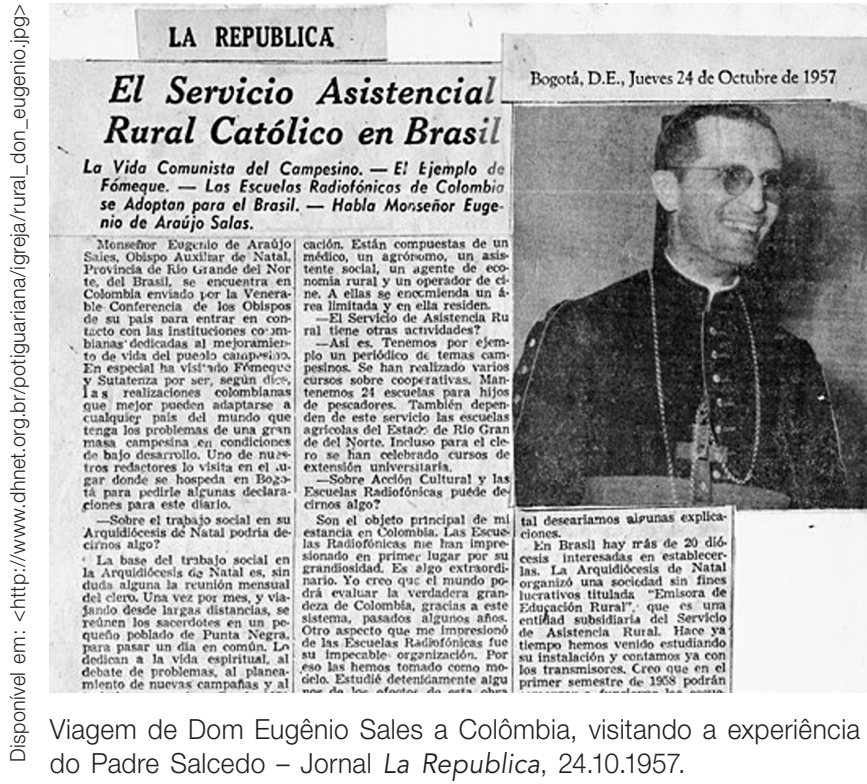

formas de ensino, possibilitando uma educação a distância e adotando uma postura mais democrática, atingindo um maior contingente de alunos, sobretudo na década de 1960, que contabilizava um grande índice de analfabetismo.

O rádio à pilha, com amplo poder de penetração nas áreas rurais - grande parte sem acesso à energia elétrica -, além de ser um veículo com baixo custo em relação à instalação de escolas, torna-se o principal meio de comunicação a ser utilizado pelo MEB a favor da educação. Ressaltando, segundo Kaplun ${ }^{8}$, que a educação pelo rádio não se restringe à alfabetização, mas implica também a transmissão de valores, a promoção humana, estimulando a reflexão e o nível de consciência de cada homem na transformação de seu meio natural, econômico e social.
A partir dos bons resultados obtidos com as escolas radiofônicas no $\mathrm{RN}$, surge o MEB, que amplia o alcance da educação a outros estados brasileiros, ensinando a classe popular a ler, escrever e conscientizar-se, utilizando o rádio como veículo mediador de conhecimentos. Nesse contexto, o rádio apresentou-se como um veículo eletrônico de comunicação que contribuiu para a abertura de novas

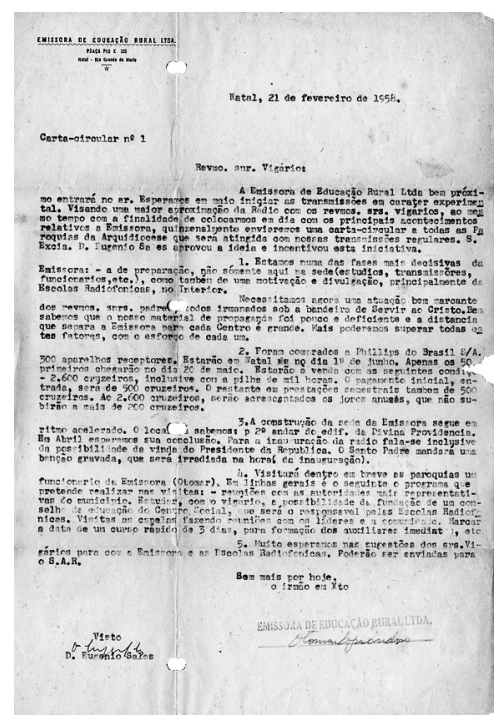

Carta circular de n. 1, da Emissora de Educação Rural de Natal, enviada por Dom Eugênio Sales e Otomar Lopes Cardoso, em 1958, informando os preparativos finais para a primeira transmissão da Rádio Rural, bem como a compra de 300 aparelhos receptores.

\section{ANALISANDO AS AULAS RADIOFÔNICAS DA EMISSORA RURAL}

A Rádio Rural transmitiu aulas produzidas pelos professores de Natal, seguindo os preceitos do MEB, mas também recorrendo às necessidades locais dos alunos aos quais se dirigiam, pois os professores costumavam visitar as escolas radiofônicas nas comunidades.

Analisamos duas aulas radiofônicas que remetem aos três planos de atuação do MEB, a saber: o plano da conscientização da realidade, da formação de atitudes

8. BARBOSA FILHO, André. Gêneros radiofônicos: os formatos e os programas em áudio. São Paulo: Paulinas, 2003. 
e da instrumentalização do aluno para a ação. No primeiro plano, os discursos veiculados tinham como objetivo conscientizar o ouvinte sobre a realidade na qual estava imerso, questionando os aprendizes e promovendo a reflexão, como mostra a aula do dia 22 de agosto de 1963, transmitida no horário das $20 \mathrm{~h}$ às $20 \mathrm{~h} 34$.

O discurso dessa aula radiofônica começa remontando uma dramatização ouvida pelos alunos na aula anterior, cujo enfoque era a relação de pais e filhos. A dramatização não estava descrita no roteiro, tampouco tivemos acesso ao áudio dela. Porém, de acordo com a fala da professora, indicada no roteiro, após a escuta da dramatização, foram direcionadas três perguntas aos alunos, a saber: 1) O que vocês acham da vida dessa família?; 2) O dever de Antônio é apenas o de dar sustento aos filhos?; 3) A educação dos filhos é dever somente da mãe? Que acham vocês?

Em seguida, a professora emite seu discurso, que versa sobre a realidade da família apresentada na dramatização, defendendo um papel feminino atuante, bem como a união da mãe e do pai na administração da casa e na criação dos filhos:

Em primeiro lugar a vida dessa família, como de muitas outras, é sacrificada. Famílias em que a mulher não tem seu devido valor. Não queremos dizer de maneira nenhuma que a mulher seja somente um objeto de enfeite, isso nunca, mas uma pessoa que administra sua casa pensando em conjunto. São duas cabeças, duas pessoas a pensarem juntas. Os filhos são crianças que dependem tanto do pai quanto da mãe. O pai não deve somente dar o sustento. Ele e a mãe se complementam. E jamais deveriam agir separadamente [...]. Eles são um misto de amor, carinho, compaixão e cumplicidade (aula I, trecho I).

Esse discurso sobre a família está relacionado à proposta pedagógica do MEB, que pretendia oferecer aos alunos uma educação de base, voltada para a formação e realização pessoal. A voz da professora emite um discurso conscientizador com vistas a tornar os jovens e adultos conscientes dos seus deveres como membros de uma família, nos papéis de pai e mãe. Além disso, quando relacionamos os discursos a suas condições de produção, percebemos a postura evangelizadora da Igreja Católica apontando para a cumplicidade do casal na criação dos filhos, evolvidos pelo amor, carinho e compaixão.

Quanto à argumentação, a professora relembra os questionamentos introduzidos pela dramatização para depois defender sua tese a favor do papel da mulher no seio da família. Esses questionamentos configuram-se na técnica argumentativa da modalidade interrogativa, capaz de dialogar com os alunos, possibilitando a reflexão acerca do que foi transmitido e instigando o aprendiz a tirar conclusões.

O momento para a reflexão do ouvinte acontecia quando o operador de áudio colocava no ar uma trilha musical a fim de condicionar o aluno a exprimir suas opiniões, coordenados por monitores que auxiliavam os educandos no debate. Vemos aqui o caráter dialógico da interação, pois o professor dirige-se ao aluno por meio de perguntas, instigando-o a se posicionar. 


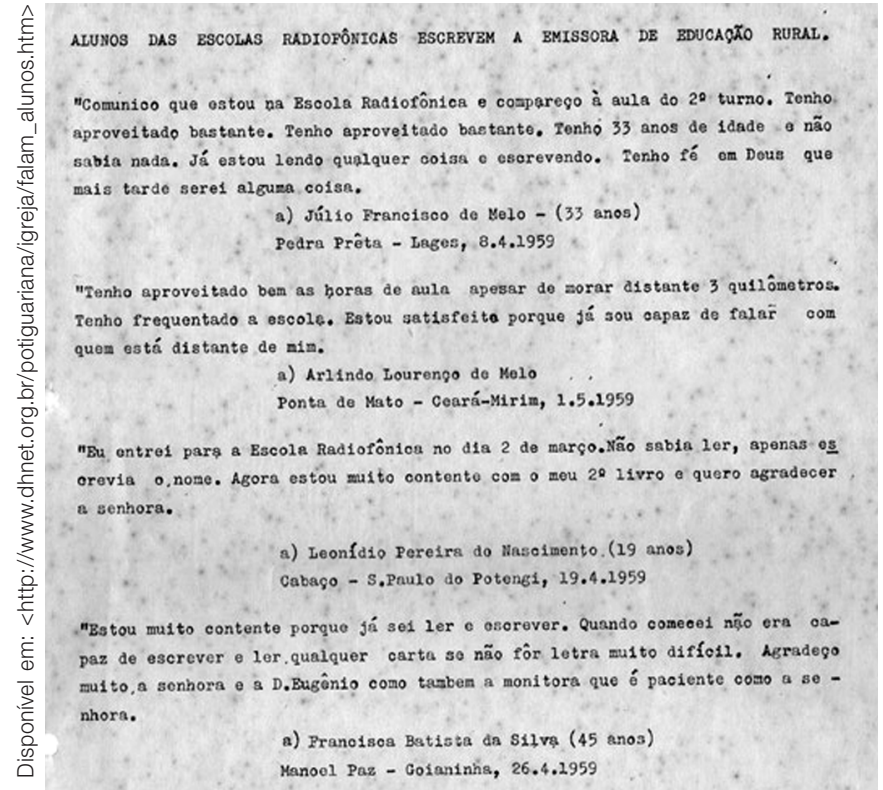

Os alunos das escolas radiofônicas no RN comentam sobre o processo de educação pelo rádio.
As dramatizações eram usadas como técnica de recurso de presença para dinamizar as aulas no processo de convencimento. A dramatização pertence ao gênero de entretenimento e é definida por Barbosa ${ }^{9}$ como uma representação do real e do cotidiano, utilizando a linguagem radiofônica. A dramatização, como formato dentro da aula radiofônica, do gênero educativo-cultural, também proporciona dinamicidade à transmissão da aula porque é capaz de utilizar

a voz humana, a música, os efeitos sonoros e o silêncio para criar cenários, despertar sentimentos e envolver o receptor a ponto de fazê-lo transformar o som em imagem mental, processo chamado de imaginação.

Mas além de conscientizar, o MEB também queria promover nos ouvintes a formação de atitudes diante da realidade com vistas à ação do aluno, como podemos verificar na aula do dia 05 de novembro de 1964, que objetiva persuadir os alunos a lutarem por justiça, usando a técnica argumentativa do valor de justiça:

Temos consciência de que é preciso lutar por Justiça e que só poderemos levar adiante esta luta se estivermos organizados. Sabemos que é através da luta que renovamos a nós mesmos e renovamos o mundo. Sabemos também que Deus quer nosso esforço pelo o amor e pela justiça. Assim sendo, não podemos parar. Temos que ir adiante, enfrentando com mais firmeza nossa luta pela construção de uma sociedade onde reina justiça, paz e amor entre os homens [...] (Aula II, trecho I)

Nesse caso, lutar por justiça é empreender esforços para sair da submissão, batalhar por mudanças sociais, já que o discurso volta-se para jovens e adultos da zona rural, marginalizados social e economicamente. A luta é colocada como o meio capaz de renovar os sujeitos e o mundo, é um instrumento de ação que necessita um povo organizado, por meio de sindicatos e cooperativas, por exemplo. Além disso, o professor/locutor também se refere a Deus para fundamentar a necessidade de lutar, enfatizando a concepção doutrinária da Igreja Católica, que envolvia ideologicamente os discursos do MEB em busca de uma sociedade mais justa.

9. BARBOSA FILHO, op. cit., p. 117. 
comunicação \& educação • Ano XVI • número 2 • jul/dez 2011

\section{CONSIDERAÇÕES FINAIS}

O MEB questionou e negou a realidade injusta vivida pelos alunos, falando de um lugar social que entende e representa a classe trabalhadora. Os discursos difundidos pela Rádio Rural de Natal defendiam a formação de sujeitos livres e ativos, que unidos pudessem conduzir à libertação do povo. As técnicas argumentativas não atuaram sozinhas, pois o momento histórico de desigualdades sociais que inundava o Brasil na década de 1960 criava na classe marginalizada o desejo de justiça, tornando-os mais susceptíveis à adesão das teses apresentadas. Assim, podemos dizer que a argumentação transmitida pelo rádio tinha como princípio vencer junto com o aluno, ou melhor, promover convencimento e persuasão a partir dos próprios anseios dos alunos. Mas será que esse processo argumentativo foi manipulação? Não lemos assim, entretanto, ainda que tivesse sido, foi também condição e modo de expressão das insatisfações das classes populares.

Além disso, as aulas promoviam uma interação mediada e dialógica com o aluno, presumindo o interlocutor, já que a própria pedagogia do MEB fundamentava-se no desenvolvimento de uma educação com a participação do aluno. Percebemos também o uso de certas potencialidades do rádio, tais como: linguagem clara e direta, recursos de sonoplastia, inter-relação entre o gênero educativo-cultural (aulas) e o gênero de entretenimento (dramatização), para mediar os discursos e conquistar a adesão dos alunos, num período em que o rádio ainda era o principal veículo de comunicação no Estado do Rio Grande do Norte.

\section{REFERÊNCIAS BIBLIOGRÁFICAS}

ABREU, Antônio Suárez. A arte de argumentar: gerenciando razão e emoção. 3. ed. São Paulo: Ateliê Editorial, 2001.

BAKHTIN, Mikhail. Marxismo e filosofia da linguagem. São Paulo: Hucitec, 1995.

BARBOSA FILHO, André. Gêneros radiofônicos: os formatos e os programas em áudio. São Paulo: Paulinas, 2003.

FÁVERO, Osmar (Org.). Cultura popular e educação popular: memória dos anos 60. 2. ed. Rio de Janeiro: Edições Graal, 2001.

PÊCHEUX, Michel. Semântica e discurso: uma crítica à afirmação do óbvio. Trad. Eni Pulcineli Orlandi. 3. ed. Campinas: Editora da UNICAMP, 1997.

PERELMAN, Chaïm; TYTECA, Lucie Olbrechts. Tratado da argumentação: a nova retórica. Trad. Maria Ermantina Galvão. São Paulo: Martins Fontes, 1996.

THOMPSON, John B. A mídia e a modernidade: uma teoria social da mídia. Petrópolis (RJ): Vozes, 1998. 